\title{
日本語版健康増進ライフスタイルプロフィール
}

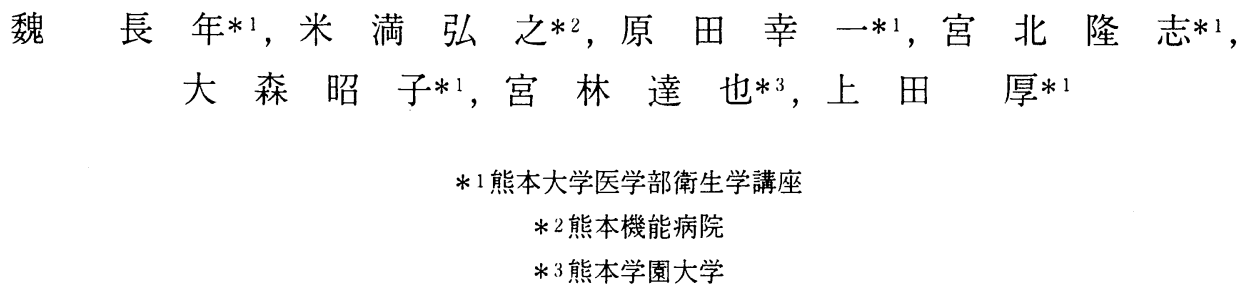

\section{A Japanese Language Version of the Health-Promoting Lifestyle Profile}

\author{
Chang-nian WEI*1, Hiroyuki YONEMITSU*2, Koichi HARADA*1, Takashi MIYAKITA*1, \\ Shoko OMORl*1, Tatsuya MIYABAYASHI ${ }^{* 3}$ and Atsushi UEDA*1 \\ *I Department of Hygiene, Kumamoto University School of Medicine, Kumamoto \\ *2 Kumamoto Kinoh Hospital, Kumamoto \\ ${ }^{*}$ Kumamoto Gakuen University, Kumamoto
}

\begin{abstract}
The development and initial psychometric evaluation of a Japanese version of the HealthPromoting Lifestyle Profile II (HPLP II) is described. The 52-item instrument was translated into Japanese and was found to be culturally relevant and reliable in a pilot study. The Japanese version was then administered to adiverse but predominantly Japanese group of 337 subjects residing in northern Japan. The Japanese version of the HPLP II was evaluated using factor analysis and reliability measurement. Six factors similar to those isolated previously during psychometric assessment of the English language version were extracted. Those six dimensions comprise the HPLP II subscales of: 1. Health responsibility, 2. Spiritual growth, 3. Physical activity, 4. Interpersonal relations, 5. Nutrition, and 6. Stress management. The alpha reliability coefficient for the total scale was 0.94 and the 2-week retest reliability was 0.91 ; the alpha coefficients for the subscales ranged from 0.70 to 0.87 . The Japanese language version of the HPLP II appears to have sufficient validity and reliability for use by researchers who wish to describe the health-promoting components of lifestyle among the Japanese population and to explore differences and similarities in the health-promoting lifestyle of Japanese and American subjects or those of other ethnic groups. Further evaluations of measurement with different populations appears warranted. This instrument will enable researchers to investigate patterns and determinants of health-promoting lifestyle, as well as the effects of interventions to alter the lifestyle.
\end{abstract}

Key words: health-promoting lifestyle（健康增進ライフスタイル), questionnaire（調査票）

1990年のアメリカでは，年間約 $2,148,000$ 人の死亡 が報告され，その死因の上位には，心疾患（1位）， 癌 ( 2 位), 脳血管疾患 ( 3 位), 事故 (4 位), 慢性 肺疾患（5位）が，ついで，肺炎とインフルエンザ, 糖尿病，自殺，肝疾患，HIVがあげられている1。 McGinnisらは，これらの死者の約 $50 \%$ が非健康的な ライフスタイルを原因としていることを疫学的に明

受付 1999年 5 月 10 日 受理 1999 年 9 月 3 日

Reprint requests to: Atsushi UEDA,

Department of Hygiene, Kumamoto University School of Medicine, Honjo 2-2-1, Kumamoto City, Kumamoto Pref, 860 Japan

TEL: +81(96)373-5104 FAX: +81(96)373-5108
らかにしている2。一方，日本の死因構造においても， 悪性新生物, 脳血管疾患, 心疾患, 肺炎, 事故など アメリカの死因順位と比較的類似した疾患が上位に あげられているか。

このことは，わが国においてもそれぞれの死亡の 要因を明らかにする上で, ライフスタイルの要素を 解析する必要のあることを示唆するものと思われる。

ライフスタイルは, 人々の毎日の生活活動あるい は生活の仕方と定義されている4。Ardell らは，健康の 視点から, ライフスタイルは, 個人の全ての行動で あるほか，人の健康リスクに影響する行動も含んで いるものとしている。WileyとCamachoはゅ, ライフス タイルでみられる行動は, 自主的で, 日常生活様式 
により調節できるものであることから，ライフスタ イルのあり方が健康状態を規定する大きな要素であ ると考えている。このように，ライフスタイルは， 健康の保持, 增進という観点から重要な基本的な要 素であることが共通の認識になりつつある。

一方，WHOの提唱するヘルスプロモーションの構 成要素は，1）健康なライフスタイルの促進，2） 健康な生活環境の提供の増大，3）地域社会活動の 強化，4）健康サービス事業の効果の再調整，5） 健康政策の施行となっている。従って, ヘルスプロ モーションは, 疾病予防と同一の概念ではなく, ま た疾病あるいはある特殊な健康問題に対する対策と も異なり，より質の高い健康を目指すために取りあ げられる行動であり》，自己成長や心の安らぎを求め る幸福のヘルスケアであると理解されているッ。また， Pender 9) らは, ヘルスプロモーションとは, 疾病ある いは健康問題に対する予防行為ではなく，正しい方 向への成長と変化への接近 (approach) 行為であり, 疾病予防は, 回避 (avoidance) 行為であるとしてい る。

このように，ライフスタイルを基盤としたヘルス プロモーションの推進が, 地域の保健医療活動を支 える理念と技術として認識され，その手法の検討と 応用が，様々な地域を対象に追求され始めている。 しかしながら，我が国においては，かかる観点から 個々のライフスタイルのあり方を把握し評価する手 法は未だ確立されていない。この際，Walkerらが 10) 健康增進ライフスタイル (Health-promoting lifestyle) を唱導し，これを“個人における健康維持あるいは 健康レベルの向上を達成するために，また，自己実 現と自己満足が得られるために行われる自発的，多 局的行動であること”と定義づけていることは注目 に值するものと思われる。Walkerらは，このライフ スタイルを評価するために, Pender ${ }^{11) ら に よ り “ ラ ~}$ イフスタイルと健康習慣に関する調査票”として開 発されたLifestyle and Health Habits Assessment (LHHA) に基づいて, Health-Promoting Lifestyle Profile I（HPLP I）を開発した。当初この調査票は, 48項目の質問で構成され, Health-Promoting Lifestyle の尺度として，6つのサブ尺度（1. Self-Actualization; 2. Health Responsiblity; 3. Exercise; 4. Nutrition; 5. Interpersonal Support; 6. Stress Management）を備え ていた。1996年にここの調査票はHealth-Promoting Lifestyle Profile II（HPLP II）として更新され，52項目 の質問に構成し直された。この調査票では, HealthPromoting Lifestyleの尺度は，1. Health Responsibility; 2. Physical Activity; 3. Nutrition; 4. Spiritual Growth; 5. Interpersonal Relations; 6. Stress Managementという 6 つのサブ尺度に変更された。この調査票は, 現在で は, アメリカ合衆国の様々な地域や集団で使われて おり，既にこの調查票を用いた 50 余りの論文が報告
されている。これらの論文の対象者は, 若年者 ${ }^{22}$, 中 年者 ${ }^{13)}$, 高齢者 ${ }^{14)}$, 大学生 ${ }^{15)}$, 工場の労働者 ${ }^{16)}$, 勤労女 性 ${ }^{17)}$ ，家庭婦人 ${ }^{187}$ ，癌患者 ${ }^{197}$ ，更年期女性 ${ }^{201}$ であった。 また, HPLP II については中国語版 ${ }^{21.22)}$ やスペイン語 版 ${ }^{23)}$ の調査票が作成され，実際の調査が行われている。 我々はこの調査票のライフスタイル評価のツールと しての有用性に着目し, HPLP II の日本語版を作成し， これを用いてパイロット集団に対する調査を行い, 日本語版HPLP II の信頼性と妥当性, およびその解析 と活用法について検討した。

\section{方 法}

\section{1.日本語版HPLP II 作成の手順}

心理学, 運動生理学, 栄養学, 社会医学の専門家 の協力で英語原版HPLP II の52項目を日本語に翻訳 し，さらに，アメリカに 15 年間在住した日本人研究 者（アメリカでPh. D. 取得）と日本に10年間在住し, 翻訳の仕事をしているアメリカ人の協力でそれの逆 翻訳を行った。著者らとバイリンガルらは，原版の 質問の本意と言外語句の意味を損なわないように, 翻訳しにくい単語や文章はより正確な日本語表現に なるよう考慮した。まず，最初に翻訳した日本語版 HPLP II について，各対象者に分かりやすく回答でき るかどうか検証をした。即ち, 年齢17歳から83歳ま での60名に対して, 性, 年齢, 学歴, 職業, 社会経 験などを考慮し，1回目の予備調査を行った。また， 被調査者に対して調査票の内容について不明な点あ るいは回答しにくい質問について自由記述的に意見 を求め, 調査票の改訂のための参考とした。得られ た回答の結果を分析し, 調査票を再改訂し,さらに 94 名の対象者に対して 2 回目の予備調査を行った。 この調査票では, 対象者は全項目の質問に回答して おり, 調査票として問題のないことが確認された。 以上の手続きに従って日本語版HPLP II 調査票（健康 増進ライフスタイルプロフィール）を作成した。

\section{2. 調査対象}

対象者の選択には，男女に大きな偏りのないこと と, なるべく幅広い年齢, 多様な職業や学歴の構成

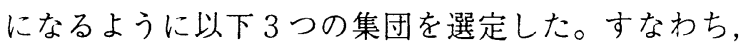
某大学夜間部学生 (167名), 某医療サービス機関の 職員（110名）と健康教室の参加者 (83名)，合計360 名を抽出した。それらに調查の目的を説明し，同意 を得たあと，作成した調査票を用いた調査が行われ た。調査票は無記名で記入され, 留置法で回収され た。337名 (93.6\%) の完全回答された調査票の結果 を有効データとして分析した。対象者は，男性142名， 女性195名であり, 平均年齢は39.3（18～84）歳, 男 性37.1（18～84）歳, 女性39.3（18～83）歳であった。 23 名 $(6.4 \%)$ の不完全回答者については, 完全回答 
者と性，年歯構成に有意な差異はみられなかった。 1 回目の調査の個人デー夕（性年齢分布など）の解 析結果から，医療サービス機関の対象者（110名）の 個人データは，全サンプル（337名）と最も類似して いたことが示された。そこで，その集団の110名が第 2 回目の再調査の対象者として選定された。1回目 の調査の 2 週間後に, 1 回目の調査と同じ無記名, 留置法で 2 回目の調査が行われ，93名（男性39名, 女性 54 名）（回収率85\%）（平均年龄35.7（18～67）歳） の回答を得た。

\section{3. 日本語版HPLP II の構造}

日本語版HPLP II は，英語原版HPLP II と同じ52項 日の質問（付表）で構成されている。質問の順序も 同一である。全ての質問に対する回答は 4 つの選択 枝が設定され，それぞれ, Never, Sometimes, Often, Routinelyとなり，それぞれの日本語訳を全くない (しない)，あまりない（しない），時々ある（する）， いつもある（する）とした。これらのスコア化に対 し，1の回答には 1 点を，2には，2 点，3には， 3 点，4には 4 点を与えた。従って，このスコアは， より高い点がより良好なライフスタイルを現すよう に設定されている。健康增進ライフスタイルのスコ アは，52項目の平均得点とした。また，各サブ尺度 のスコアは，それぞれのサブ尺度に含まれる質問項 目の平均得点とした。

\section{4.デー夕の統計学的解析}

337 人の調査票についてSPSS6.0版を用いて, Cronbach’s Alpha法で日本語版HPLP II の信頼性, 調 査票と各サブ尺度の内部的一貫性を解析した ${ }^{21)}$ 。また， 主成分抽出法（Principal components extraction）を用 いて，斜交回転で因子構成（サブ尺度）を分析し， 調査票の質問項目構成の妥当性を解析した。英語原 版HPLP II と同様に，抽出因子数は 6 つで，抽出因子 の負荷量は，0.35以上に設定した。全ての統計分析は， 性別, 年歯令群別（20歳以下 69 名，21 40歳 94 名, 41 $\sim 60$ 歳103名, 60 歳以上 71 名の 4 群), 抽出 3 集団 (某大学夜間部学生, 某医療サービス機関の職員, 健 康教室参加者）別に行った。

\section{結 果}

1. 各質問項目のスコア

表 1 に, 男女別に各質問項目を得点順位別に示し た。平均得点の高位に, “朝食を食べる（平均スコア

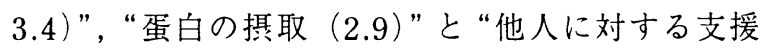
(2.9)”があげられ，低位に，“健康づくり（1.5）, “運動量のコントロール（1.5）”と“運動目標の設定 (1.5)”があげられた。

2．日本語版HPLP II の信類性
Table 1 Scores on the all items of the Japanese version of HPLP II

\begin{tabular}{|c|c|c|c|}
\hline Item & Male & Female & Mean \\
\hline Eat breakfast & 3.1 & 3.6 & 3.4 \\
\hline Eat protein & 2.7 & 3.1 & 2.9 \\
\hline Express concern / love & 2.8 & 2.9 & 2.9 \\
\hline Praise others easily & 2.6 & 3.0 & 2.8 \\
\hline Get enough sleep & 2.5 & 2.9 & 2.8 \\
\hline Eat vegetables & 2.5 & 2.9 & 2.7 \\
\hline Touch / be touched & 2.5 & 2.9 & 2.7 \\
\hline Spend time with close friends & 2.7 & 2.8 & 2.7 \\
\hline Maintain meaningful interpersonal relationships & 2.6 & 2.8 & 2.7 \\
\hline Do exercise during daily activities & 2.6 & 2.6 & 2.6 \\
\hline Eat carbohydrates & 2.6 & 2.6 & 2.6 \\
\hline Get support & 2.4 & 2.8 & 2.6 \\
\hline Know what is important & 2.4 & 2.6 & 2.5 \\
\hline Feel happy / content & 2.4 & 2.6 & 2.5 \\
\hline Attend health care programs & 2.2 & 2.7 & 2.5 \\
\hline Seek guidance & 2.2 & 2.7 & 2.5 \\
\hline Read labels & 2.1 & 2.8 & 2.5 \\
\hline Eat milk foods & 2.5 & 2.6 & 2.5 \\
\hline Settle conflicts with others & 2.4 & 2.7 & 2.5 \\
\hline Allow for daily relaxation time & 2.4 & 2.6 & 2.5 \\
\hline Be optimistic & 2.3 & 2.6 & 2.5 \\
\hline Look forward to future & 2.4 & 2.4 & 2.4 \\
\hline Set long-term goals & 2.3 & 2.6 & 2.4 \\
\hline Discuss concerns / problems & 2.1 & 2.6 & 2.4 \\
\hline Prevent tiredness & 2.2 & 2.6 & 2.4 \\
\hline Use stress control methods & 2.4 & 2.4 & 2.4 \\
\hline Try new challenges & 2.3 & 2.2 & 2.3 \\
\hline Follow a exercise plan & 2.2 & 2.3 & 2.3 \\
\hline Limit sugars & 2.1 & 2.5 & 2.3 \\
\hline Feel life has a purpose & 2.1 & 2.3 & 2.2 \\
\hline Find days challenging & 2.4 & 2.1 & 2.2 \\
\hline Be aware of strengths/ weaknesses & 2.0 & 2.3 & 2.2 \\
\hline Do moderate physical activity & 2.2 & 2.1 & 2.2 \\
\hline Do vigorous exercise 3 times / week & 2.4 & 2.1 & 2.2 \\
\hline Choose low-calorie foods & 1.8 & 2.4 & 2.2 \\
\hline Meet needs for intimacy & 2.0 & 2.4 & 2.2 \\
\hline Meditate / relaxation & 2.1 & 2.2 & 2.2 \\
\hline Maintain balance between work and play & 2.0 & 2.3 & 2.2 \\
\hline Growing / changing & 2.0 & 2.2 & 2.1 \\
\hline Question M.D. & 2.0 & 2.3 & 2.1 \\
\hline Inspect physical changes & 1.9 & 2.2 & 2.1 \\
\hline Eat fruits & 2.0 & 2.2 & 2.1 \\
\hline Have pleasant bedtime thoughts & 2.0 & 2.1 & 2.1 \\
\hline Discuss health concerns & 1.5 & 1.9 & 1.8 \\
\hline Report any symptoms to M.D. & 1.5 & 2.0 & 1.8 \\
\hline Do recreational activities & 2.0 & 1.7 & 1.8 \\
\hline Do stretching exercise & 1.9 & 1.7 & 1.8 \\
\hline Discuss with M.D. / get second opinion & 1.5 & 1.7 & 1.7 \\
\hline Read books about health & 1.3 & 1.8 & 1.6 \\
\hline Seek information to take good care of myself & 1.3 & 1.6 & 1.5 \\
\hline Check pulse rate & 1.3 & 1.6 & 1.5 \\
\hline Set exercise intensity & 1.3 & 1.6 & 1.5 \\
\hline
\end{tabular}

日本語版HPLP II のAlpha值は0.94で，高い内部的一 貫性が示された。 2 週間後に行われた 93 人に対する 再調査でも，Alpha值は，0.91と高値を示した。また， 各サブ尺度のAlpha值は，0.70０.87であった。同様 
に2 週間後に行われた調査についても，各サブ尺度 のAlpha値は $0.68 \sim 0.85$ と同様の成績が得られた（表 2 )。男女別に見ると，日本語版HPLP II のAlpha值は， それぞれ0.95および0.97で，各サブ尺度のAlpha值は， それぞれ0.65〜0.83および0.75〜0.88であった。また， 年齢群別にみると, 日本語版HPLP II のAlpha值は, 0.90〜0.95，各サブ尺度のAlpha值は，0.68～0.86であ った。抽出 3 集団別にみても，日本語版HPLP II の Alpha值は0.92 0.95，各サブ尺度のAlpha值は0.65 0.82 ，と各群間に差異はみられなかった。

\section{3. 因子分析}

因子構成の選出条件は，それぞれの項目の因子負 荷量が 0.35 より大きいものとした。表 3 に示されるよ うに，日本語版HPLP II は，第 1 因子（9項目）とし て健康意識（Health Responsibility），第 2 因子（9 項 目）として精神成長（Spiritual Growth），第 3 因子 （8 項目）として身体運動 (Physical Activity)，第 4 因子（9項目）として人間関係（Interpersonal Relations)，第 5 因子（9 項目）として栄養 (Nutrition)，第6因子（8項目）としてストレス管理 (Stress Management）と意味づけられる構成をとっ ていることが示された。これは，英語原版のサブ尺 度の構成（項目編成）と同一であった。また, 性別, 年龄群別, 抽出 3 集団別の因子分析の結果では, い ずれのグループにおいても因子の構造に大きな差異 は認められなかった。表 4 に，因子分析により抽出 された因子の固有值と各因子によって説明される分 散のパーセンテージを示した。

\section{4. 各サブ尺度のスコア}

日本語版HPLP II に対する回答結果を解析するため に，それぞれのサブ尺度ごとにスコア化し，表 5 に， その平均值, 標準偏差, 最大值および最小值を示し

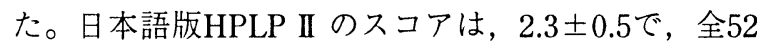
それぞれの質問項目のスコアは，3.6 1.1と比較的広 い得点範囲にあった。

$\chi^{2}$ 適合度検定を用いて, 性別, 年齢群別に日本語 版HPLP II のスコアと各サブ尺度のスコア分布を検定 したところ，それぞれのスコアの分布は，正規分布 状態であることが認められた。

\section{考 察}

今回我々が翻訳開発した日本語版HPLP II の妥当性 と信頼性を検討するために設定された対象集団は,

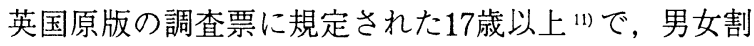
合に大きな偏りがなく，年齢の幅が広く，多様な職 業や学歴を有する対象者により構成されている。し かしながら，因子分析におけるそれぞれのサブ尺度 の構成には性別, 年齢別, 抽出集団別に有意な差異
Table 2 Internal consistency of the Japanese version of HPLP II and six subscales

\begin{tabular}{lccc}
\hline & Number of & \multicolumn{2}{c}{ Cronbach's $a$} \\
\cline { 3 - 4 } Subscale & Items & first test $(\mathrm{n}=337)$ & re-test $(\mathrm{n}=93)$ \\
\hline Health Responsibility & 9 & 0.84 & 0.81 \\
Spiritual Growth & 9 & 0.87 & 0.85 \\
Physical Activity & 8 & 0.85 & 0.84 \\
Interpersonal Relations & 9 & 0.73 & 0.75 \\
Nutrition & 9 & 0.70 & 0.68 \\
Stress Management & 8 & 0.80 & 0.81 \\
& & & \\
Health-Promoting Lifestyle & 52 & 0.94 & 0.91 \\
\hline
\end{tabular}

は認められなかった。

英語版HPLP II の因子抽出では，因子負荷量が 0.40 以上として設定されているが111)，日本語版HPLP II の 因子負荷は 0.35 以上として設定した。その理由として 翻訳上の問題があげられる。例えば，因子 1 にある 質問の48番, “Feel connected with some force greater than myself”を，「自分より強いもの，偉大なもの， 例えば自然の力と神の存在といったようなものを感 じていますか」と翻訳したが，このような宗教に関 する問題は，必ずしも一般の日本人に答え易い問題 ではないと考えられた。同じく因子 5 では，質問の 31番, "Touch and am touched by people I care about" を,「家族と友人とのスキンシップを大切にしていま すか」と翻訳した。ここの“Touch”は物理的な“触 るや接触”を意味している。日本人とアメリカ人は, “触るや接触”の意味に対する受け取り考えかたがか なり違うと思われている。このような質問の日本語 訳は非常に困難であった。また, 栄養面や人間関係 やストレス管理においては, 日本人の生活習慣との 考えかたを考慮して日本語翻訳をしたため，必ずし も原版の意味を表していないところもありうる。し たがって, 一部の質問項目の因子負荷量が英語原版 のそれより若干小さくなったと考えているが，サブ 尺度とそれらの質問項目の間には有意な強い相関が 認められている。また，表 3 に示すように, “set exercise target” と “Meet needs for inttimacy” の質 問項目では，それぞれの因子負荷量が前者は，因子 3 （0.41）の, 後者は, 因子 4（0.39）のそれより因 子 1 （0.44と0.50）のそれがより大きい值を示してい る。これらの結果からみれば, 日本語版調査票のサ ブ尺度の構成を変えること, あるいはこれらの質問 項目を削除することが必要になるが，これらの設問 の本意と, 特に, 原版調査票の構造を確保すること を考慮し，また，これらの質問項目は所属因子と有 意な強い相関（>0.35）があるため, 日本語版調査票 としては英語原版調査票と同じ構造を選定した。

日本語版調査票は 6 つの健康増進ライフスタイル サブ尺度で構成された。すなわち，1 。健康意識 (Health Responsibility)；2．精神成長 (Spiritual 
Table 3 Factor loading and factor structure for the Japanese version of HPLP II (N=337)

\begin{tabular}{|c|c|c|c|c|c|c|}
\hline & Factor 1 & Factor 2 & Factor 3 & Factor 4 & Factor 5 & Factor 6 \\
\hline Item & & & & & & \\
\hline Discuss health concerns & 0.78 & & & & & \\
\hline Report any symptoms to M.D. & 0.75 & & & & & \\
\hline Seek information to take good care of myself & 0.74 & & & & & \\
\hline Seek guidance & 0.66 & & & & & \\
\hline Read books about health & 0.65 & & & & & \\
\hline Inspect physical changes & 0.60 & & & & & \\
\hline Attend health care programs & 0.59 & & & & & \\
\hline Question M.D. & 0.59 & & & & 0.37 & \\
\hline Discuss with M.D. / get second opinion & 0.54 & & & & & \\
\hline Feel life has a purpose & & 0.74 & & & & \\
\hline Look forward to future & & 0.65 & & & & \\
\hline Set long-term goals & 0.36 & 0.63 & & & & \\
\hline Feel happy / content & & 0.63 & & & & \\
\hline Growing / changing & & 0.62 & & & & \\
\hline Find days challenging & & 0.62 & & & & \\
\hline Know what is important & & 0.54 & & & & \\
\hline Try new challenges & & 0.38 & & 0.45 & & \\
\hline Be aware of strengths / weaknesses & & 0.35 & & & & \\
\hline Do vigorous exercise 3 times / week & & & 0.82 & & & \\
\hline Do moderate physical activity & & & 0.79 & & & \\
\hline Follow a exercise plan & & & 0.72 & & & \\
\hline Do recreational activities & & & 0.66 & & & \\
\hline Do stretching exercise & & & 0.59 & & & \\
\hline Check pulse rate & 0.52 & & 0.53 & & & \\
\hline Set exercise intensity & 0.44 & & 0.41 & & & \\
\hline Do exercise during daily activities & & & 0.39 & & & \\
\hline Get support & & & & 0.72 & & \\
\hline Discuss concerns / problems & & & & 0.59 & & \\
\hline Maintain meaningful interpersonal relationships & & 0.55 & & 0.56 & & 0.39 \\
\hline Express concern / love & & & & 0.54 & & \\
\hline Settle conflicts with others & & & & 0.46 & & \\
\hline Meet needs for intimacy & 0.50 & 0.38 & 0.37 & 0.39 & & \\
\hline Spend time with close friends & & 0.36 & & 0.37 & & 0.36 \\
\hline Touch / be touched & & 0.43 & & 0.36 & & \\
\hline Praise others easily & 0.37 & & & 0.36 & & \\
\hline Eat milk foods & & & & & 0.73 & \\
\hline Eat fruits & & & & & 0.66 & \\
\hline Eat vegetables & & & & & 0.61 & \\
\hline Limit sugars & 0.48 & & & & 0.56 & \\
\hline Eat protein & & & & & 0.50 & \\
\hline Eat breakfast & & & & & 0.44 & \\
\hline Choose low-calorie foods & & & & & 0.37 & \\
\hline Read labels & 0.40 & & & & 0.36 & \\
\hline Eat carbohydrates & & & & & 0.35 & \\
\hline Get enough sleep & & & & & & 0.59 \\
\hline Maintain balance between work and play & & & & & & 0.57 \\
\hline Allow daily relaxation time & & & & & & 0.52 \\
\hline Have pleasant bedtime thoughts & & & & & & 0.48 \\
\hline Be optimistic & & & & & & 0.45 \\
\hline Prevent tiredness & 0.35 & 0.37 & & & & 0.42 \\
\hline Meditate / relaxation & & & 0.38 & & & 0.38 \\
\hline Use stress control methods & & & & 0.35 & & 0.37 \\
\hline
\end{tabular}


Table 4 Variance explained by six factors on the Japanese version of HPLP II

\begin{tabular}{lccc}
\hline \multicolumn{1}{c}{ Factors } & Eigenvalue & \% of Variance & Cumulative \% \\
\hline Health Responsibility & 14.16 & 27.2 & 27.2 \\
Spiritual Growth & 3.26 & 6.3 & 33.5 \\
Physical Activity & 2.69 & 5.2 & 38.7 \\
Interpersonal Relations & 1.73 & 3.3 & 42.0 \\
Nutrition & 1.65 & 3.2 & 45.2 \\
Stress Management & 1.59 & 3.1 & 48.2 \\
\hline
\end{tabular}

Growth）；3．身体運動（Physical Activity）；4．人間 関係（Interpersonal Relations）； 5. 栄養 (Nutrition); 6.ストレス管理（Stress Managment）と特徴づけ られるサブ尺度を現しているものと思われた。これ は，英語原版の調査票のサブ尺度（1. Health Responsibility; 2. Physical Activity; 3. Nutrition; 4. Spiritual Growth; 5. Interpernal Relations; 6. Stress Management）の順位と異なるが，その質問項目の構 成は，両者とも同一のものであった。さらに，他の 翻訳版とも全く同一の構成であった ${ }^{21,22,23) 。 こ の よ う ~}$ に，因子分析の結果から日本語版調査票およぴ各サ ブ尺度における質問項目の構成は妥当であることが 確認された。調査票の妥当性が確保された理由は, 翻訳の過程に専門家の協力を得て，質問の内容を出 来るだけ日本人の生活習慣，日本文化，宗教，等を 考慮して，日本語への翻訳を行ったことであると考 えられる。たとえば，英語原版HPLP II は，全ての質 問に対する回答選択はNever; Sometimes; Often; Routinelyとなっているが，これらに相当する日本語 翻訳を，それぞれ，全くない（しない），時々ある (する)，よくある(する)，いつもある（する）とし た。しかし，これらの日本語訳は，必ずしも全ての 質問に応じている回答とは言えないことは子備調査 の段階で判明した。したがって，原語の意味を伝え るために，それぞれの質問回答の頻度，程度，強度 について原版の著者（Walker）と意見を交換しなが ら，質問の本意を正確に表現することを前提として 適切な日本語に翻訳した。例えば，質問の10番， “Exercise vigorously for 20 or more minutes a weak" を，「20分以上の比較的激しい運動を，週あるいは月 に何回していますか」と翻訳し，その回答に，(1)全 くしていない, (2)月に1〜2 回はしている，(3)週に 1〜2 回はしている, (4)週に3 回以上している, と いう具体的な頻度を示して翻訳した。また，質問24 番では, “FeeI content and at peace with myself”を, 「今の自分に満足していますか」と翻訳し，回答とし て，(1)不満足，(2)どちらかといえば不満足，(3)どち らかといえば満足，(4)満足，と程度を回答するよう

に翻訳した。

各サブ尺度ごとに，スコアを算出すると，表 5 の ごとくで, 健康増進ライフスタイルの総合スコアは, $2.3 \pm 0.5$ で，各項目のスコアは，3.6 1.1と比較的広
い幅を持っており，しかも，正規性が示された。 このように，我々が翻訳開発した日本語版HPLP II は，日本人の健康増進ライフスタイルの構成要素を 解析するために，または他の民族や国の人口集団の デー夕と比較するために有用な測定ツールであるこ とが認められた。

今後，多くの研究者と協同でこの調査票を用いた デー夕を集積することにより，様々な人口集団にお けるライフスタイルの様態を，それぞれの集団の特 性に対応して評価するとともに，それに基づいた適 切なライフスタイルのあり方を提示して行くことが 可能になるものと考えられる。

Table 5 Scores on the Japanese version of HPLP II

\begin{tabular}{lccc}
\multicolumn{1}{c}{ Subscales } & Mean & S.D. & Range \\
\hline Health Responsibility & 2.0 & 0.6 & $1.0 \sim 3.9$ \\
Spiritual Growth & 2.4 & 0.6 & $1.1 \sim 3.9$ \\
Physical Activity & 2.0 & 0.6 & $1.0 \sim 3.8$ \\
Interpersonal Relations & 2.6 & 0.5 & $1.7-3.9$ \\
Nutrition & 2.6 & 0.6 & $1.2 \sim 4.0$ \\
Stress Management & 2.4 & 0.5 & $1.1 \sim 3.6$ \\
& & & \\
Health-Promoing Lifestyle & 2.3 & 0.5 & $1.1 \sim 3.6$ \\
\hline
\end{tabular}

\section{謝 辞}

本研究を実施するにあたり，専門知識にご協力頂 いた鹿屋体育大学芝山秀太郎教授，田畑泉教授，大 平充宣教授，または言語翻訳にご協力頂いた熊本学 園大学海外事情研究所Kirk Masden所長と熊本大学外 国人の日本語教育講師福山寿子先生に深謝いたしま す。調査にご参加を頂きました熊本県の住民に厚く 感謝の意を表します。

なお，この質問票の作成と併用は，HPLP II 原版を 作成したSusan Walker教授の許可を得て行った。

\section{文 献}

1) National center for health statistics. Advance report of final mortality statistics, 1990 . Hyattsvill, Md: US Dept of health and human services; 1993. Monthly vital statistics report, Vol 41, No. 7 .

2) Michael MJ and Foege WH. Actual causes of death in the United States. JAMA $1990 ; 270: 2207-12$.

3) 厚生省1997年「国民衛生の動向」p51.

4) Singer JE. The need to measure life-Style. International Review of Applied Phsychology $1982 ; 31: 303-15$.

5) Ardell DB. The nature and implications of high level wellness, or why "normal health" is a rether sorry state of existence. Health Values: Achieving High Level Wellnessm $1979 ; 3:$ 17-24. 
6) Wiley JA, Camacho TC. Life-Style and future health: Evidence from the Alameda County study, Preventive Medicine $1980 ; 9: 1-21$.

7) Laffrey SC. Health promation: relevance for nuysing. Top clin. Nursing $1985 ; 7: 29-38$.

8) Brubaker BH. Health promotion: A linguistic analysis. Advanced Nursing Science 1983 ; 5 : 1-14.

9) Pender NJ. Health promotion in nursing practice. Appleton \& Lange, East Norwalk, Znd ed. 1987 ; 911.

10) Walker SN, Sechrist KR, Pender NJ. The healthpromoting life-style profile: Development and psychometric characteristics. Nursing Reseach $1987 ; 36: 76-81$.

11) Pender NJ. Health promotion in nursing practice. Norwalk, CT: Appleton-Century-Crofts.

12) Walker SN, Volkan K, Sechrist KR, Pender NJ. Health-promoting life style of older adults: Comparisons with young and middle-aged adults. Correlates and patterns. Advances in Nursing Science $1988 ; 11: 76-90$.

13) Fleetwood J, Packa DR. Determinants of healthpromoting behaviors in adults. J. Cardiovascular Nursing $1991 ; 5: 67-79$.

14) Duffy ME. Daterminants of health-promoting lifestyles in older persons. Image, J. Of Nursing Scholarship $1993 ; 25: 23-28$.

15) Oleckono WA, Lacconiere MJ. Risk taking behaviors and other correlates of seat belt use among university students. Public Health 1990 ; $104: 155-64$.
16) Weitzel MH. A test of the health promotion model with blue collar workers. Nursing Research 1989 ; 38 : 99-104.

17) Pender NJ, Walker SN, Sechrist KR, FrankStromberg MF. Predicting health-promoting lifestyles in the workplace. Nursing Research $1990 ; 39: 326-32$.

18) Walker LO, Best MA. Well-being of mothers with infant children: A premimilary comparison of employed women and home-makers. Women and Health $1991 ; 17: 71-89$.

19) Franker-Stromborg M, Pender NS, Walker SN, Sechrist KR. Determinants of health-promoting lifestyle in ambulatory cancer patients. Social Science \& Medicine $1990 ; 31: 1159-68$.

20) Ali NS. Bennett SJ. Postmenopausal women: Factors in osteoporosis preventive behaviors. J. Of Gerontological Nursing $1992 ; 18: 23-32$.

21) Huang YH. Chiou CJ. Assessment of the healthpromoting lifestyle profile on reliablity and validity. Kao-Hsiung Hsueh Ko Tsa Chih Kaohsiung J. Of medical Sciences $1996 ; 12: 529-37$.

22) Chen MY, Liao JC, Liao JH, Chou CC. The preliminary study of health-promoting lifestyles of public health nurses. Nursing reserch (Nursings' Association of the Republic of China) $1994 ; 2: 41$ 51.

23) Waiker SN, Kerr MJ, Pender NJ. Sechrist KR. A spanish version of the health-promoting lifestyle profile. Nursing Research 1990 ; 38 : 268-73.

24) SPSS Professional Statistics 6.1. 
付表

日本語版健康増進ライフスタイルプロフィール

この調査票は, あなたの現在の生活のあり方と健康の関係をチェックするものです。 各項目の質問に対してできるだけ正確に漏れなくお答えください。自分の行動の頻度 に一番近いところに○を付けてください。

1. 自分の問題や心配ごとを親しい人に打ち明けることがありますか。
1. 全くない
2.あまりない
3、時々ある
4.いつもある

2. 低脂肪, 低飽和脂肪酸 (魚類等), 低コレステロールの食事を心がけていますか。
1. 全く心がけていない
2。あり心がけていない
3. 時々心がけている
4. いつも心がけている

3. 体調の変化や症状を, 医師や医療関係者（医師，保健婦，看護婦等）に話すことがありますか。
1. 全くない
2.あまりない
3. 時々ある
4.いつもある

4. 計画的に運動していますか。
1. 全くしていない
2.あまりしていない
3. 時々している
4. いつもしている

5.十分な睡眠をとっていますか。
1. 全くとっていない
2.あまりとっていない
3. 時々とっている
4.いつもとっている

6. 自分は少しずつ良い方向に成長していると感じますか。
1. 全く感じない
2.あまり感じない
3. 時々感じる
4. いつも感じる

7.他の人がやったことを気軽にほめることがありますか。
1. 全くない
2.あまりない
3. 時々ある
4.いつもある

8. 砂糖の多い食物をひかえていますか。
1. 全くひかえていない 2.あまりひかえていない
4. いつもひかえている

9.健康に関する記事を読んだり,テレビの番組を見たりしますか。
1. 全くしない
2.あまりしない
3. 時々する

10. 20 分以上の比較的激しい運動を, 週あるいは月に何回していますか（速歩, サイクリング, エアロビクス, 階段上り等)。

1. 全くしていない 2.月に1２回はしている 3. 週に1２回はしている 4. 週に3回以上はしている

11. 毎日の生活において, リラックスのための時間をとっていますか。
1. 全くとっていない
2. あまりとっていない 3 . 時々とっている
4.いつもとっている

12. 意義のある人生を送っている自信がありますか。
1. 全くない
2.あまりない
3. 時々ある
4. いつもある

13. 他の人と有意義で充実した関係を保っていますか。
1. 全く保っていない 2.あまり保っていない
3. 時々保っている
4. いつも保っている

14. 毎食,ごはん, パン, 缅類を $1 \sim 2$ 杯食べていますか。
1.1食も食べていない 2 . 1 食は食べている
3. 2 食はたべている
4. 3 食はたべている

15. 医療関係者（医師, 保健婦, 看煡版
1 . 全くしない

2、あまりしない

3. 時々する

4. いつもする

16. 30４0分の歩行のような，軽いまたは適度の運動を週あるいは月に何回していますか。
1. 全くしていない
2.月に1ー3回はしている
3. 週に2 2 回はしている
4. 週に5回以上はしている

17. 自分では変えることのできないことは，しかたがないものとして受け入れますか。
1. 全く受け入れない
2.あまり受け入れない
3. 時々受け入れる
4. いつも受け入れる

18. 自分自身の将来に期待することがありますか。
1. 全くない
2.あまりない
3. 時々ある
4. いつもある

19. 親友と過ごす時間をつくるよう心がけていますか。

1. 全く心がけていない 2 .あまり心がけていない 3 . 時々心がけている 4.いつも心がけている 20.1日に，果物を何回食べていますか。
1. 全く食べていない
2. 1 回は食べている
3. 2 回は食べている
4. 3〜4回は食べている 
21. 医師の指示に疑問があるときは別の医師に相談しますか。
1。全くしない
2.あまりしない
3. 時々する
4. いつもする

22.レクリェーションとしてスポーツ（水泳，

1. 全くしていない 2. あまりしていない

をしていますか。

23. 就寝前にはできるだけ楽しいことを考えるようにしていますか。
1. 全くしていない
2.あまりしていない
3. 時々している

4. いつもしている

24. 今の自分に満足していますか。
1. 不渵
2.どちらかといえば不满足
3.どちらかといえば満足 4 . 㳑足

25. 他人に対して暖かい思いやりの気持ちを持つことができますか。
1. 全くできない
2、あまりできない
3. 時々できる
4.いつもできる

26. 毎食野菜を食べていますか。
1. 全く食べていない
2. 1 回は食べている
3. 2 回は食べている
4. 食事毎に食べている

27. 自分の健康のことについて医療関係者（医師，保健婦，看護婦等）に相談することがありますか。
1. 全くない
2.あまりない
3. 時々ある
4. いつもある

28. ストレッチ体操を週あるいは月に何回していますか。
1. 全くしていない
2.月に1３回はしている
3. 週に1〜2回はしている
4. 週 3 回以上はしている

29. ストレス解消のためにしていることがありますか。
1. 全くない
2.あまりない
3。時々ある
4.いつもある

30. 自分の人生の目標に向かって努力していますか。
1. 全くしていない
2.あまりしていない
3. 時々している
4. いつもしている

31. 家族あるいは親友とのスキンシップを大切にしていますか。

$$
\text { 1. 全くしていない 2. あまりしていない３．時々している 4. いつもしている }
$$

32.1日に乳製品（牛乳, ヨーグルト,チーズ等）を何回ロにしていますか。

1. 全くロにしていない 2.1回は口にしている 3.2回は口にしている 4.3回は口にしている

33. 定期的に自分の健康状態（体重や血圧等）をチェックしていますか。
1. 全くしていない
2.あまりしていない 3 . 時々している
4.いつもしている

34. 日常生活に運動を取り入れていますか（昼食をとるのに，食堂まで歩いていったり， エレベーターを使わず階段を上ったり，車をわざと駐車場のはずれに止めてできるだけ歩く等)。

1. 全く取り入れていない 2. あまり取り入れていない 3. 時々取り入れている 4. いつも取り入れている

35. 仕事とレジャーのバランスを考えていますか。
1. 全く考えていない
2. あまり考えていない 3 ．時々考えている
4. いつも考えている

36. 一日一日が面白く有意義だと感じますか。
1. 全く感じない
2.あまり感じない
3. 時々感じる
4. いつも感じる

37.心のやすらぎ (親友関係) を求めるため努力をしていますか。
1。全くしていない
2.あまりしていない
3. 時々している
4. いつもしている

38. 肉類, 鶏肉, 魚, 卵, 豆類, ナッツ類のいずれかを1日に何種類か食べていますか。

1. 全く食べていない 2.1 種類は食べている 3.2 種類は食べている 4.3 種類は食べている

39.どうしたら自分はより健康的になるかを，医療関係者（医師，保健婦，看菜婦等）に相談しますか。

40. 運動中自分の脈拍をチェックしていますか。
1. 全くしない
2.あまりしない
3. 時々する
4. いつもする

1. 全くしていない

2.あまりしていない

3. 時々している

4. いつもしている

41. 1 日に15 20分間, 気晴らしを

瞑想にふけったりしますか。

42. 自分の人生で何が大切かを認識していますか。
2.あまりしない
3. 時々する
4.いつもする

1. 全く認識していない 2 ．あまり認識していない 3 ．時々認識している

4. いつも認識している

43. 親しい人に話をきいてもらうことがありますか。
1. 全くない
2、あまりない
3.時々ある
4、いつもある 
44. 食品のラベルに書いてある栄養成分, 脂肪, 塩分の含有量を確かめることがありますか。
1. 全くない
2.あまりない
3. 時々ある
4、いつもある

45. 健康管理に関する学習会に参加することがありますか。
1. 全くない
2.あまりない
3. 時々ある
4、いつもある

46. 目標心拍数で運動していますか。
1. 全くしていない
2.あまりしていない
3. 時々している
4. いつもしている

47. 疲れすぎないように自分のペースを保っていますか。
1. 全く保っていない
2、あまり保っていない
3. 時々保っている
4.いつも保っている

48. 自分より強いもの偉大なもの, 例えば自然の力とか神の存在といったようなものを感じていますか。
1. 全く感じていない
2.あまり感じていない
3 . 時々感じている
4. いつも感じている

49. 話し合いや妥協によって他の人との摩擦を和らげることがありますか。
1. 全くない
2.あまりない
3。時々ある
4、いつもある

50。朝食を食べていますか。
1. 全く食べていない
2.あまり食べていない
3. 時々食べている
4.いつも食ベている

51. 困ったときには，相談にのってくれる人，指導してくれる人を探しますか。
1. 全くしない
2。あまりしない
3 . 時々する
4. いつもする

52. 新しいことにチャレンジしていますか。
1. 全くしていない
2.あまりしていない
3. 時々している
4.いつもしている

c S.N. Walker, K. Sechrist, N. Pender, 1995. Reproduction without the author's express written consent is not permitted. Permission to use the scale may be obtained from Susan Noble Walker, College of Nursing, University of Nebraska Medical Center, Omaha, NE 68198-5330, U.S. 